\title{
Seasonal variation of Leptospira species in pond and paddy field water samples in Thrissur district
}

\author{
Nair Archana $S^{\mathrm{a}}$., K. Vrinda Menon ${ }^{\mathrm{b}},{ }^{\mathbb{D}}$ C. Latha $^{\mathrm{c}}$ and B. Sunil ${ }^{\mathrm{d}, \mathrm{e}}$ \\ ${ }^{a}$ Research Scholar, Department of Veterinary Public Health, College of Veterinary and Animal Sciences, Mannuthy, \\ Kerala Veterinary and Animal Sciences University, India \\ ${ }^{b}$ Assistant Professor, Department of Veterinary Public Health, College of Veterinary and Animal Sciences, Mannuthy, \\ Kerala Veterinary and Animal Sciences University, India \\ 'Dean, College of Veterinary and Animal Sciences, Mannuthy, Kerala Veterinary and Animal Sciences University, India \\ 'Professor and Head, Centre of Excellence in Meat Science and Technology (Meat Technology Unit), Department of \\ Livestock Products Technology, College of Veterinary and Animal Sciences, Mannuthy, Thrissur, Kerala, India \\ eProfessor, Department of Veterinary Public Health, College of Veterinary and Animal Sciences, Mannuthy, Kerala \\ Veterinary and Animal Sciences University, India
}

Corresponding author: K. Vrinda Menon | email: vrinda@kvasu.ac.in

Co-authors: NAS: archana.nairkl@gmail.com ; LC: 1atha@kvasu.ac.in; BS: $\underline{\text { sunil@kvasu.ac.in }}$ Received: 16-08-2020, Accepted: 29-08-2020, Published online: 11-10-2020

\begin{abstract}
Leptospirosis is an acute anthropozoonotic infection occurring worldwide caused by a pathogenic spirochete belonging to the genus Leptospira. The highest occurrence of leptospirosis in tropical countries is directly related to heavy rainfall and flooding. The changing rainfall pattern in the Western Ghats with rainless days during the monsoon months is reportedly affecting normal climatic condition of Kerala. Leptospires are able to survive in an environment with high humidity and moderate temperature.. The present study was undertaken to study the seasonal variation in occurrence of Leptospira spp. in pond and paddy field water in Thrissur district of Kerala. The samples were collected in two seasons i.e. monsoon (June to September) (Season-1) and summer (February to May) (Season-2) for the identification of Leptospira spp. The water samples were subjected to PCR for identification of the organism. The temperature and $\mathrm{pH}$ of water samples were recorded at the time of collection. The different physicochemical parameters of water in these two sources were in the range of $\mathrm{pH}$ (6.5- 7.9), conductivity (85$150 \mu \mathrm{s} / \mathrm{cm}$ ), salinity (0.02- $0.12 \mathrm{psu})$, turbidity (5-50NTU), dissolved oxygen (6-8 mg/L). Out of the 80 samples analysed, 52 (23 from monsoon and 29 from summer) samples detected $16 \mathrm{Sr} R N A$ at 430 bp and hence was positive for Leptospira species. The pathogenicity of the positive isolates were analysed by detecting the virulence gene viz., lipl 32, lipl 21 and lipl 41 respectively. The results revealed that out of the total isolates of Leptospira, 23 and 21 isolates were positive for lipl 21 and lipl 41 in monsoon and summer seasons respectively. Out of the total 85 paddy field water samples collected, 17 samples were found to be positive for Leptospira spp. The virulence gene lipl 21 was detected in three samples in summer season. However, lipl 32 and lipl 41 genes were not detected in any of the samples. The results of the present study demonstrated the ubiquitous nature of the organism in environment in the both seasons. The contaminated environment can hence be one of the sources for the increase in the frequency of human and animal leptospirosis in Kerala.
\end{abstract}

Keywords: $\quad$ Leptospira spp., Leptospirosis, Paddy field water quality, lipl 32, lipl 21 and lipl 41

doi: https://doi.org/10.51128/jfas.2020.A009/ How to cite this article: Archana S. N., Menon, K. V., Latha, C. and B. Sunil, 2020. Seasonal variation of leptospira species in pond and paddy field water samples in Thrissur district. Journal of Food and Animal Sciences, 01 (01): 48 - 52.

Copyright: Archana et al. Open Access. This article is distributed under the terms of the Creative Commons Attribution 4.0 International License (http://creativecommons.org/licenses/by/4.0/), which permits unrestricted use, distribution, and reproduction in any medium, provided you give appropriate credit to the original author(s) and the source, provide a link to the Creative Commons license, and indicate if changes were made. The Creative Commons Public Domain Dedication waiver (http://creativecommons.org/publicdomain/zero/1.0/) applies to the data made available in this article, unless otherwise stated. 


\section{Introduction}

Leptospirosis is a zoonotic infection occurring worldwide caused by a pathogenic spirochete belonging to the genus Leptospira. It is estimated that 1.03 million cases of leptospirosis occur every year worldwide. In human beings, the disease can manifest as mild febrile illness to severe life threatening forms like Weil's disease. The highest occurrence of leptospirosis in tropical countries is directly related to heavy rainfall and flooding. The infection is generally transmitted to humans by water that has been contaminated by animal urine, which comes in contact with skin abrasions or with the mucous membranes. The moist and alkaline soil, bentonite clay of rice fields lengthens the survival of leptospires in the environment and has major role in endemicity of infection in particular areas. The changing rainfall pattern in the Western Ghats with rainless days during the monsoon months is reportedly affecting normal climatic condition of Kerala. According to reports of Directorate of Health Services 2017, Kerala, from January 2016 to May 2017 a total of 2229 confirmed cases of Leptospira were reported with 1.48 per cent mortality.

Certain recreational activities such as different water sports, travelling to highly endemic areas, cultural factors and socioeconomic circumstances have been recognized as risk factors for occurrence of disease. Leptospira are maintained in the genital tract and renal tubules of wild and domestic animals and are excreted with urine into the environment where they can survive for several months depending on favorable conditions such as moderate temperature and humidity. Rodents are recognized as important mammal reservoirs of Leptospira spp (Guerra, 2009 and Meerburg et al., 2009)., which only present mild chronic disease or are asymptomatic, and shed infectious organisms in the urine for their lifetime . Humans may be infected indirectly from animals by contact with contaminated water, soil or mud in a moist environment, or by direct contact with urine, fresh carcasses or organs (Vinetz, 2001)

The genus Leptospira is divided into three strains which include pathogenic, intermediate and saprophytic strains. The saprophytic species does not cause any infection but are commonly found in water and soil. About 268 serovars have been identified which were further classified under 17 species of Leptospira and Leptonema. The endemicity of the disease in Kerala requires to study the role of environment in maintaining the organism in different environmental water sources. Hence, considering all the above facts the current study was designed with the objective of studying the seasonal variation of Leptospira spp. in, pond and paddy field water samples in Thrissur district.

\section{Materials and methods}

\section{Collection of Sample}

The study period ranged from June 2016 to May 2017 which was divided into two seasons, Monsoon season from June to September (Season-1) and the summer season from February to May (Season-2). All the samples were collected from areas in and around Thrissur. A total of 80 pond water samples and 85 paddy field water samples were collected.. Five hundred milliliter of water was collected aseptically in a sterilized plastic bottle and transported to laboratory at normal environmental temperature i.e. $28-30^{\circ} \mathrm{C}$. For estimation of dissolved oxygen, all the samples were separately collected in amber coloured bottles.

\section{Processing of sample}

The $\mathrm{pH}$ and temperature of the samples were noted at the time of collection. Other physiochemical parameters viz. turbidity, salinity, conductivity and dissolved oxygen were recorded by using Multiparameter water analyser (Thermo Fisher Scientific, Singapore). All the water samples collected were subjected to PCR as per the procedure explained by Tansuphasiri et al. (2006) and Vishak (2015). The Leptospira DNA isolation was carried out using Nucleospin Tissue DNA isolation kit (Macherey-Nagel, Germany). Four oligonucleotide primers targeting the 16Sr RNA, lipl 32, lipl 21 and lipl 41 were used in the study for detection of Leptospira organism. The PCR amplification was carried out in an automated thermal cycler (Eppendorf Master Cycler, Germany) . The detection of PCR product was carried out by electrophoresis in 1.5 per cent agarose gel in Tris Boric acid EDTA (TBE) electrophoresis buffer (1X). The gel was visualized under UV transilluminator and the images were documented on gel documentation system (Bio-Rad Laboratories, USA). The data obtained were subjected to statistical analysis using the SPSS software version 21 .

\section{Results and Discussion}

The presence of pathogenic and saprophytic organisms in pond water in season one and season two was identified by PCR. Out of the 80 pond water samples analysed, 52 (23 from monsoon and 29 from summer) samples detected $16 S r R N A$ at 
Table 1. Overall occurrence of Leptospira spp. in pond and paddy field water

\begin{tabular}{|c|c|c|c|c|c|c|c|c|c|}
\hline \multirow{3}{*}{$\begin{array}{l}\text { Sl. } \\
\text { No. }\end{array}$} & \multirow{3}{*}{ Sources } & \multicolumn{4}{|c|}{ Monsoon } & \multicolumn{4}{|c|}{ Summmer } \\
\hline & & \multirow{2}{*}{$\begin{array}{l}\text { No. of } \\
\text { Samples } \\
\text { analysed }\end{array}$} & \multicolumn{3}{|c|}{ Leptospira positive samples } & \multirow{2}{*}{$\begin{array}{c}\text { No. of } \\
\text { Samples } \\
\text { analysed }\end{array}$} & \multicolumn{3}{|c|}{ Leptospira positive samples } \\
\hline & & & $\begin{array}{l}\text { Sapro } \\
\text { phytic }\end{array}$ & $\begin{array}{l}\text { Patho } \\
\text { genic }\end{array}$ & Per cent & & $\begin{array}{l}\text { Sapro } \\
\text { phytic }\end{array}$ & $\begin{array}{l}\text { Patho } \\
\text { genic }\end{array}$ & Per cent \\
\hline 1 & $\begin{array}{l}\text { Paddy } \\
\text { field }\end{array}$ & 45 & 12 & 0 & 26.66 & 40 & 2 & 3 & 12.50 \\
\hline 2 & Pond & 40 & 15 & 8 & 57.50 & 40 & 14 & 15 & 72.50 \\
\hline
\end{tabular}

Table-2 : Physicochemical parameters of pond water

\begin{tabular}{|c|c|c|c|c|}
\hline \multirow{2}{*}{ S1. No. } & \multirow{2}{*}{ Parameters } & Monsoon & Summer & \multirow{2}{*}{ Z- value } \\
\cline { 3 - 4 } & $\mathrm{pH}$ & Mean \pm S.E. & Mean \pm S.E. & \\
\hline 2 & Conductivity & $182.70 \pm 21.93$ & $84.57 \pm 5.87$ & $4.322^{* *}$ \\
\hline 3 & Turbidity & $37.53 \pm 20.30$ & $13.81 \pm 5.23$ & $1.131^{\mathrm{ns}}$ \\
\hline 4 & Salinity & $1.10 \pm 0.68$ & $0.04 \pm 0.00$ & $1.554^{\mathrm{ns}}$ \\
\hline 5 & Dissolved oxygen & $6.68 \pm 0.169$ & $6.55 \pm 0.22$ & $0.501^{\mathrm{ns}}$ \\
\hline 6 & Temperature & $23.28 \pm 0.46$ & $28.85 \pm 0.24$ & $10.645^{* *}$ \\
\hline
\end{tabular}

${ }^{*}$ - $(\mathrm{p} \leq 0.05)$, ns- non-significance, ${ }^{* *}-(\mathrm{p} \leq 0.01)$

Table 3. Physicochemical parameters of paddy field water samples in different seasons

\begin{tabular}{|c|c|c|c|c|}
\hline \multirow{2}{*}{ S1. No. } & \multirow{2}{*}{ Parameters } & Monsoon & Summer & \multirow{2}{*}{ Z- value } \\
\cline { 3 - 4 } & & Mean \pm S.E. & Mean \pm S.E. & \\
\hline 1 & $\mathrm{pH}$ & $6.90 \pm 0.47$ & $6.68 \pm 0.74$ & $2.555^{*}$ \\
\hline 2 & Conductivity & $124.69 \pm 6.92$ & $91.49 \pm 5.24$ & $3.860^{* *}$ \\
\hline 4 & Turbidity & $67.49 \pm 17.84$ & $61.37 \pm 29.31$ & $0.756^{\mathrm{ns}}$ \\
\hline 5 & Salinity & $0.07 \pm 0.01$ & $0.04 \pm 0.002$ & $3.391^{* *}$ \\
\hline 6 & Dissolved oxygen & $6.65 \pm 0.15$ & $5.62 \pm 0.30$ & $3.098^{* *}$ \\
\hline
\end{tabular}

${ }^{*}$ - $(\mathrm{p} \leq 0.05)$, NS- non-significance, ${ }^{* *}-(\mathrm{p} \leq 0.01)$ 
430bp. and hence was positive for Leptospira species. The pathogenicity of the positive isolates were analysed by detecting the virulence gene viz., lipl 32, lipl 21 and lipl 41 respectively. The results revealed that out of the total isolates of Leptospira, 8 and 15 isolates were positive for lipl 21 and lipl 41 in monsoon and summer seasons respectively and hence were pathogenic. However, lipl 32 was not detected in any of the samples. The results are shown in Table-1.

Similar results were observed by Neethu, (2015) who analyzed 30 pond water samples in Thrissur, Kerala, of which six samples were found positive for pathogenic Leptospira by PCR. According to Tansuphasiri et al., (2006), a direct PCR amplification method does not show viability of organisms, but it helps to find out the presence of the target DNA fragments in the analyzed water samples. Weddell, (2015) reported that pathogenic leptospires are mainly associated with stagnant bodies of water which provide optimal environments for growth and retains viability. Most of the water samples collected from pond in present study was stagnant. The water in some of the ponds was used for bathing of humans and animals which would have got contaminated through their urine. Moreover, the burrows of the rodents were near to the pond water sources so urine of these rodents may have also contaminated the pond water. The fast growing saprophytes suppress the growth of pathogenic leptospires (Murgia et al., 1997) and may be the reason for reduced occurrence of pathogenic strains in the current study.

The $\mathrm{pH}$ and temperature of paddy field water was found to be in a range of 6.5 to 6.9 and $29-31^{\circ} \mathrm{C}$ in both the seasons respectively Out of the total 85 paddy water samples collected, 17 samples were found to be positive for $16 \mathrm{Sr} R \mathrm{RA}$ gene. The virulence gene lipl 21 was detected in three samples in summer season. However, lipl 32 and lipl 41 genes were not detected in any of the samples analysed. Ryu et al. (1966) in their study revealed that Leptospira were able to maintain their viability at a range of temperature 0 to $30^{\circ} \mathrm{C}$ and at a $\mathrm{pH}$ value ranged between 7 to 8 in paddy field water, which may be the reason attributed to lower positivity of Leptospira in paddy field samples collected in present study. Pui et al. (2017) reported that cultivated paddy field with more rodent inhabitation was found to be contaminated with the organism and in the finding of present study, as 7.5 per cent occurrence of pathogenic organism was seen in the water samples collected from cultivated paddy field from Maddakathara where large number of rodent population were noticed.

The physicochemical analysis of pond water is shown in Table 2. and of paddy field water is shown in Table-3.

The different physicochemical parameters of water samples affected the survival rate and growth of bacteria. Alkaline water, lower salinity (less than 0.13 per cent) temperature between $25-32^{\circ} \mathrm{C}$ and dissolved oxygen $(5-8 \mathrm{mg} / \mathrm{L})$ favoured the survival of organism in natural water sources. Gupta et al. (1996) also reported higher dissolved oxygen content of paddy field water followed by heavy rain as shown in the present study. The salinity of different water sources was found to be in range of $0.04-1.10$ psu. According to Saito et al. (2014) Leptospira are able to survive only for short period of time in 0.85 per cent $\mathrm{NaCl}$ solution and a range of $0.01-1$ psu is favorable for their growth as observed in present study.

In the present study there was no significant difference in the occurrence of the organisms in both the seasons. In Thrissur during the study period there was a 44 per cent decline in South West and 68 per cent decline in North East Monsoon rainfall. The decrease in average rainfall in both the seasons might be the reason for less variation in occurrence in both the seasons. NCDC, (2015) reported that heavy concentrated rainfall leaves a lot of surplus water which causes obstruction of natural drainage of rain water and accumulation for longer periods. The water logged areas force the rodent population to abandon their burrows and contaminate the stagnant water by their urine. So chances of occurrence of Leptospirosis may increases in rainy season than in summer. However, the of human disease occurrence during both the seasons were observed in the State. Hence, environmental monitoring of water sources, early diagnosis, and proper treatment will prevent the further spread and occurrence of leptospirosis.

\section{Authorship contribution statement}

Nair Archana S.: Conducted the research; K. Vrinda Menon: Conceptulised the research work reviewed orginal draft; B. Sunil and C. Latha: Supervision, Writing - review \& editing

\section{Acknowledgment}

The authors are thankful to the Dean, College of Veterinary and Animal Sciences, Mannuthy and Kerala Veterinary and Animal Sciences University for providing necessary facilities to carry out this work 


\section{Funding}

The research funding provided by Kerala Veterinary and Animal Sciences University is gratefully acknowledged.

\section{Declaration of Competing Interest}

All authors declare that there exist no commercial or financial relationships that could, in any way, lead to a potential conflict of interest.

\section{References:}

Guerra M.A. 2009. Leptospirosis. J Am Vet Med Assoc. 234(4) :472-478.

Gupta, R.K., Sharma, M., Gorai, A.C. and Pandey, P.N. 1996. Impact of Coal Mining Effluents on the physico-chemical charactericts of Raja Tank, Jaria (Dhanbad). J. Freshwater Biol. 8: 63-73.

Murgia, R., Riquelme, N., Baranton, G. and Cinco, M. 1997. Oligonucleotidesspecific for pathogenic and saprophytic Leptospira occuring in water. FEMS Microbiol. Lett. 148: 27-34.

Meerburg B.G, Singleton G.R, Kijlstra A. 2009. Rodent-borne diseases and their risks for public health. Crit Rev Microbiol. 35(3):221-270.

NCDC. 2015. National Guidelines Diagnosis, Case Management Prevention and Control of Leptospirosis. Available at http://www.ncdc. gov.in

Neethu, K. P. 2015. Occurrence of Leptospirosis in dogs in Central Kerala and its public Health significance. M.V.Sc thesis, Kerala Veterinary and Animal Sciences University, Pookode, 73p.

Pui, C.F., Bilung, L.M., Apun, K. and Su'ut, L. 2017. Diversity of Leptospira spp. in Rats and Environment from Urban Areas of Sarawak, Malaysia. J. Trop. Med. 20: 18-19.

Ryu, E. and Liu, C.K. 1966. The viability of leptospires in the summer paddy water. Jpn. J. Microbiol. 10: 51-57.

Saito, M., Miyahara, S., Villanueva, S.Y., Aramaki, N., Ikejiri, M., Kobayashi, Y., Guevarra, J.P., Masuzawa, T., Gloriani, N.G., Yanagihara, Y. and Yoshida, S.I. 2014. PCR and culture identification of pathogenic Leptospira spp. from coastal soil in Leyte, Philippines, after a storm surge during Super Typhoon Haiyan (Yolanda). Appl. Environ. Microbiol. 80: 6926-6932.

Tansuphasiri, U., Chanthadee, R., Phulsuksombati, D. and Sangjun, N. 2006. Development of a duplexpolymerase chain reaction for rapid detection of pathogenic Leptospira. Southeast Asian J. Trop. Med. Public Hlth. 37: 297-308.

Vinetz J.M. 2001. Leptospirosis. Curr Opin Infect Dis. 14(5):527-538.

Vishak, C.R. 2015. Comparison of the diagnostic efficacies of Recombinant Lipl 21 and lipl 32 Proteins In Canine Leptospirosis. M.V.Sc thesis, Kerala Veterinary and Animal Sciences University, Pookode, 88p.

Weddell, C.A. 2015. Evaluation of Soil as a Risk Indicator for Human Leptospirosis in Rural, Coastal Ecuador. Graduate Theses and Dissertations, University of South Florida, 68p. 